\title{
OTIMIZAÇÃO DA TÉCNICA DA PCR PARA A DETECÇÃO DO POLIMORFISMO CYP3A4*1B E FREQUÊNCIA ALÉLICA ENTRE 60 MORADORES DE SÃO LUÍS/MA*
}

\author{
OPTIMIZATION OF PCR TECHNIQUE FOR DETECTION OF CYP3A4 * 1B POLYMORPHISM \\ AND ALLELE FREQUENCY AMONG 60 RESIDENTS OF SÃO LUIS / MA
}
OPTIMIZACIÓN DE LA PCR PARA LA DETECCIÓN DEL POLIMORFISMO CYP3A4 * $1 B$ Y FRECUENCIA DE LOS ALELOS ENTRE 60 RESIDENTES DE SÃO LUIS / MA

\author{
Bruna Aparecida Penha \\ Israel Higino de Sousa \\ Wandson Rodrigues Sousa \\ Jomar Diogo Nunes \\ Marcelo dos Santos \\ Sally Cristina Moutinho Monteiro
}

\begin{abstract}
Resumo: Os objetivos deste trabalho foram adequar a técnica de PCR para o polimorfismo CYP3A4*1B, reduzir as amplificações inespecíficas observadas e verificar a frequência alélica do polimorfismo na população de São Luís/MA. A reação de PCR foi padronizada para conter: aproximadamente 50 ng de DNA; $10 \mu \mathrm{L}$ de DNA polimerase mix (1 Unidade de enzima DNA polimerase a ser testada; $10 \mathrm{mM}$ de Tris- $\mathrm{HCl}, \mathrm{pH} 8,3 ; 50 \mathrm{mM}$ de $\mathrm{KCl} ; 2,5 \mathrm{mM}$ de $\mathrm{MgCl} 2 ; 200 \mu \mathrm{M}$ de cada desoxinucleotídeo trifosfatado - dNTP's); 10 pmol de cada iniciador e água livre de DNAse e RNAse (Prodimol) para completar o volume reacional. Optou-se por fazer a reação de PCR para um volume final de $25 \mu \mathrm{L}$. O primeiro teste foi realizado com Platinum Taq DNA Polimerase (Invitrogen Life Technologies). Depois utilizou-se as DNA polimerases Hot Star Taq DNA Polimerase (Qiagen) e Ampli Taq Gold (Invitrogen Life Technologies) e DNA Polimerase Master Mix Red (Amplicon - Neobio). Os resultados demonstraram que a PCR para o alelo CYP3A4*1B gera bandas inespecíficas que foram minimizadas com a utilização Hot Star Taq DNA Polimerase (Qiagen). Em relação ao polimorfismo a quantidade de portadores homozigotos foi de 0,33\%, a porcentagem de heterozigotos foi de $21,67 \%$ e $75 \%$ dos indivíduos foram não portadores de polimorfismo em 60 pacientes estudados. Em conclusão, este trabalho descreve a optimização e validade da análise PCR-RFLP rápida e simples, para o alelo CYP3A4*1B. Além disso, observou-se uma frequência significativa de polimorfismo para o alelo CYP3A*1B na população estudada.
\end{abstract}

Palavras-chave: Polimorfismo. CYP3A4. Citocromo P450. PCR.

\begin{abstract}
The objective of this study was to adapt the PCR for CYP3A4*1B polymorphism, reduce nonspecific amplifications observed and verify the allele frequency of the polymorphism in the population of São Luis / MA. The PCR reaction was standardized to contain: approximately $50 \mathrm{ng}$ of DNA, $10 \mathrm{uL}$ of DNA polymerase mix (1 unit DNA polymerase being tested; $10 \mathrm{mM}$ Tris- $\mathrm{HCl}, \mathrm{pH} 8.3,50 \mathrm{mM} \mathrm{KCl}, 2.5 \mathrm{mM} \mathrm{MgCl} 2$, $200 \mathrm{mM}$ of each deoxynucleotide trifosfatado - dNTP's), $10 \mathrm{pmol}$ of each primer and water-free DNAse and RNAse (Prodimol) to complete the reaction volume. We chose to do the PCR reaction to a final volume of $25 \mu \mathrm{L}$. The first test was performed with Platinum Taq DNA Polymerase (Invitrogen Life Technologies). Then we used the DNA polymerase Hot Star Taq DNA Polymerase (Qiagen) and Ampli Taq Gold (Invitrogen Life Technologies) and DNA Polymerase Mix Master Red (Amplicon - Neobio). The results demonstrated that PCR allele CYP3A4 * 1B generates nonspecific bands that were minimized using Hot Star Taq DNA Polymerase (Qiagen). In the polymorphism the amount of homozygous was $0.33 \%$, the percentage of heterozygotes was $21.67 \%$ and $75 \%$ of subjects were not carriers of polymorphism in 60 patients. In conclusion, this study described the optimization and validity of PCR-RFLP analysis fast and simple, for the CYP3A4 * 1B allele. Furthermore, there was a significant frequency of polymorphism allele * 1B CYP3A in the population.
\end{abstract}

Keywords: polymorphism, CYP3A4, cytochrome P450, PCR.

Resumen: El objetivo de este estudio fue adaptar la PCR para el polimorfismo CYP3A4*1B, reducir amplificaciones inespecíficas observadas y verificar la frecuencia de los alelos del polimorfismo en la población de San Luis / MA. La reacción de PCR fue estandarizado que contiene: aproximadamente 50 ng de DNA, $10 \mathrm{uL}$ de la mezcla de ADN polimerasa ( 1 unidad de polimerasa de ADN se está probando; $10 \mathrm{mM}$ Tris- $\mathrm{HCl}, \mathrm{pH} 8,3,50 \mathrm{mM} \mathrm{KCl}, 2,5 \mathrm{mM} \mathrm{MgCl} 2,200 \mathrm{mM}$ de cada desoxinucleótido trifosfatado - dNTP), 10 pmol de cada cebador y agua libre de DNAsa y RNAsa (Prodimol) para completar el volumen de reacción. Elegimos a hacer la reacción de PCR a un volumen final de 25 ul. La primera prueba se realizó con Hot Star Taq DNA Polymerase (Qiagen). Luego se utilizó la ADN polimerasa Hot Star Taq DNA Polymerase (Qiagen) y Ampli Taq Gold (Invitrogen Life Technologies) y DNA Polymerase Mix Master Red (Amplicon - Neobio). Los

\footnotetext{
Trabalho premiado durante o XXIV Encontro do SEMIC, realizado na UFMA entre os dias 05 a 08 de novembro de 2012.

*Artigo recebido em dezembro 2012

Aprovado em fevereiro 2013
} 
resultados demostraron que el alelo CYP3A4*1B PCR genera bandas no específicas que fueron minimizadas utilizando Hot Star Taq DNA Polymerase (Qiagen).. En el polimorfismo de la cantidad de homocigotos fue de $0,33 \%$, el porcentaje de heterocigotos fue $21,67 \%$ y el $75 \%$ de los sujetos no eran portadores del polimorfismo en 60 pacientes. En conclusión, este estudio se describe la optimización y la validez de la PCR-RFLP análisis rápido y sencillo, para el alelo CYP3A4 *1B. Además, hubo una frecuencia significativa de CYP3A polimorfismo alelo * 1B en la población.

Palabras clave: Polimorfismo CYP3A4. Citocromo P450. PCR.

\section{INTRODUÇÃO}

A variabilidade interindividual num metabolismo sob efeito de drogas pode ser decorrente de vários fatores tais como patologias, diferenças na farmacocinética e farmacodinâmica dos medicamentos, fatores ambientais, e geneticamente determinada pela variação alélica em genes que codificam, por exemplo, proteínas do citocromo P450 (EVANS; RELLING, 1999; INGELMAN-SUNDBERG; OASCARSON; MCLELLAN, 1999; OZDEMIR et al., 2000). O citocromo P450 metaboliza aproximadamente $80 \%$ dos medicamentos empregados na clínica médica e a enzima CYP3A4 participa do metabolismo de mais de $50 \%$ dos fármacos comumente utilizados ( $p$. ex.: imunossupressores, ciclosporina, eritromicina, clotrimazol, estatinas, esteroides, entre outros), pois são abundantes tanto no epitélio intestinal quanto no tecido hepático. Também participa da ativação de substâncias pré-carcinogênicas como a aflatoxinas e na indução de alguns fármacos como a dexametasona e o fenobarbital. Entretanto, a taxa de sua atividade pode variar em até 10 vezes entre diferentes populações (REBBECK et al., 1998; BALL et al., 1999; EISELT et al., 2001).

As variações na expressão da CYP3A4 podem ser causadas por fatores de inibição ou estimulação da transcrição e / ou tradução (por exemplo, administração de fármaco concomitante) e por polimorfismos genéticos. Fatores tais como a indução ou a inibição de enzimas são conhecidos por influenciar a atividade da enzima CYP3A4 (INGELMANSUNDBERG; OSCARSON; MCLELLAN, 1999). Além disso, tem sido sugerido que mutações no gene da CYP3A4 podem ser responsáveis pela variação interindividual na atividade da enzima. A este respeito, os polimorfismos foram recentemente descritos e alguns deles têm sido associados a uma baixa atividade da enzima. Estes incluem polimorfismo de um único nucleotídeo (SNP) na extremidade $5^{\prime}$ da região promotora do gene, -290A $>$ G, designado como CYP3A4V ou CYP3A4*1B (GARCIA-MARTÍN; MARTÍNEZ; PIZARRO, 2002). A frequência deste alelo em caucasianos e africanos é aproximadamente de 4 a $9 \%$ e 59 a 79\%, respectivamente (REBBECK et al., 1998, RODRIGUEZ-ANTONA; INGELMAN-SUNDBERG, 2006). Estudos sugerem, também, diferenças na expressão da atividade enzimática na dependência da etnia e gênero. A distribuição deste alelo tem sido associada a maior incidência de câncer de pulmão e próstata, mas os dados são geralmente conflitantes (RODRIGUEZANTONA; INGELMAN-SUNDBERG, 2006).

A técnica denominada Reação da Polimerase em Cadeia (PCR) é baseada na amplificação de DNA com um simples par de iniciadores (primers) de aproximadamente 10 nucleotídeos cada um, para detectar polimorfismos genéticos. As inúmeras cópias dos fragmentos de DNA produzidos servem para discriminar indivíduos, etnias ou espécies, podendo ser empregados em diversos estudos que utilizam marcadores genéticos (HARDRYS; BALICK; SCHIERWATER, 1992).

Entretanto, apesar da ser uma técnica robusta, devido a um complexo de interações dos componentes da reação e às diferentes finalidades para as quais é utilizada, um mesmo conjunto de condições de amplificação não é adequado para todas as situações, havendo, portanto, a necessidade de se estabelecer a priori as condições ótimas da reação. Diversos trabalhos têm demonstrado o efeito das concentrações de magnésio, da enzima DNA polimerase, dos primers, do DNA, dos desoxirribonucleotídeos fosfatados (dNTPs) e também dos parâmetros reacionais (temperaturas e tempos de desnaturação, anelamento e extensão; número de ciclos e Método de extração do DNA) sobre o rendimento, eficiência e especificidade de amplificação de fragmentos de DNA de humanos, plantas, bactérias, fungos, nematoides, entre outros em PCR (MEUNIER; GRIMONT, 1993; WOLFF; SCHOEN; PETERS-VAN RIJN, 1993).

Iniciadores com alto conteúdo de bases nitrogenadas citosina e guanina (C-G de 50 a $80 \%$ ), por possuírem tripla ligação, são particularmente difíceis de amplificar. A incompleta separação (desnaturação) das fitas de DNA ocorre com frequência e afeta diretamente a eficiência da amplificação por formação de estruturas secundárias e anelamentos inespecíficos. Desta maneira, considerando a estrutura dos primers para o alelo polimórfico CYP3A4*1B e sua importância no que diz respeito a interações medicamentosas (indução e inibição) com fármacos metabolizados por esta enzima e sua frequência diversificada entre caucasóides e afrodescendentes, o objetivo deste trabalho foi adequar a técnica de PCR para o polimorfismo CYP3A4*1B, reduzir as amplificações inespecíficas observadas e verifi- 
car a frequência alélica do polimorfismo na população de São Luís/MA. Para tanto, utilizou-se diferentes DNA polimerases: Platinum Taq DNA Polimerase (Invitrogen Life Technologies), Hot Star Taq DNA Polimerase (Qiagen), Ampli Taq Gold (Invitrogen Life Technologies) e DNA Polimerase Master Mix Red (Amplicon - Neobio).

\section{MATERIAL E MÉTODOS}

A otimização da técnica de reação em cadeia da polimerase foi realizada no Banco de Tumor e DNA do Maranhão (BTMA), com amostras de sangue total (com EDTA) de 60 voluntários residentes em São Luís/MA, submetidas a extração de DNA com BioPur Kit Extração Mini Spin Plus, da Empresa Biometrix Diagnóstica, conforme especificação do fabricante (técnica de extração em coluna). A quantificação do DNA genômico foi determinada por leitura espectrofotométrica em 260 $\mathrm{nm}$, em equipamento NanoVue Spectrophotometer (GE), para avaliação da sua pureza e massa (ng/uL).

Realizou-se a ciclagem em termociclador Veriti (Applied Biosystems) com primers que flanqueiam a região do CYP3A4*1B $(-392 A>G)$, gerando um produto amplificado (amplicon) de 334 pares de base ( $p b$ )
(RON et al., 2000) (Quadro 1). O processo de amplificação foi realizado nas seguintes condições de tempo e temperatura: $95^{\circ} \mathrm{C}$ - 15 minutos, $40 \times\left(94^{\circ} \mathrm{C}-1\right.$ minuto, $56^{\circ} \mathrm{C}$ - 1 minuto, $72^{\circ} \mathrm{C}-1$ minuto), $72^{\circ} \mathrm{C}-7$ minutos. A cada teste realizado foi adicionado um controle negativo.

Optou-se por fazer a reação de PCR para um volume final de $25 \mu \mathrm{L}$. O primeiro teste foi realizado com Platinum Taq DNA Polimerase (Invitrogen Life Technologies). Depois utilizou-se as DNA polimerases Hot Star Taq DNA Polimerase (Qiagen) e Ampli Taq Gold (Invitrogen Life Technologies) e DNA Polimerase Master Mix Red (Amplicon - Neobio).

A reação de PCR foi padronizada para conter: aproximadamente $50 \mathrm{ng}$ de DNA; $10 \mu \mathrm{L}$ de DNA polimerase mix (1 Unidade de enzima DNA polimerase a ser testada; $10 \mathrm{mM}$ de Tris- $\mathrm{HCl}, \mathrm{pH} 8,3$; $50 \mathrm{mM}$ de $\mathrm{KCl} ; 2,5 \mathrm{mM}$ de $\mathrm{MgCl} 2 ; 200 \mu \mathrm{M}$ de cada desoxinucleotídeo trifosfatado - dNTP's); 10 pmol de cada iniciador e água livre de DNAse e RNAse (Prodimol) para completar o volume reacional.

Após amplificação em termociclador, $8 \mu \mathrm{L}$ do produto da PCR adicionado a $2 \mu \mathrm{L}$ de gel loading (Sigma) foram submetidos à eletroforese, por aproximadamente 60 minutos, em gel de agarose na concentração de $2 \%$ corado com gel red (Uniscience). Paralelamente às amostras, um marcador de peso molecular de

Quadro 1 - Sequência da região que flanqueia o polimorfismo CYP3A4*1B e o par de iniciadores (primers) direto e reverso (forward e reverse).

CYP3A4*1B $(-392 A>G)$ rs2740574

Sequência:

AAGTATITTGGAATGAGGACAGCCATAGAGACAAGGGCAAGAGAGAGGCG ATTTAATAGATTTTATGCCAATGGCTCCACTTGAGTTTCTGATAAGAACCCA GAACCCTTGGACTCCCCAGTAACATTGATTGAGTTGTTTATGATACCTCATA GAATATGAACTCAAAGGAGGTCAGTGAGTGGTGTGTGTGTGATTCTTTGCC AACTTCCAAGGTGGAGAAGCCTCTTCCAACTGCAGGCAGAGCACAGGTGGC CCTGCTACTGGCTGCAGCTCCAGCCCTGCCTCCTTCTCTAGCATATAAACAA TCCAACAGCCTCACTGAATCACTGCTGTGCAGGGCAGGAAAGCTCCATGCA CATAGCCCAGCA

Primers: O primer forward possui duas bases modificadas, destacadas em amarelo. CYP3A4_F: 5' GGA CAG CCA TAG AGA CAACTG CA3' CYP3A4_R: 5' CTT TCC TGC CCT GCA CAG 3'

Fonte: Elaborado pelos autores

$100 \mathrm{pb}$ foi aplicado. O tampão Tris-EDTA ácido bórico (TBE) na concentração de $1 X$ foi utilizado para a corrida eletroforética (SAMBROOK; RUSSELL, 2006). Os produtos resultantes da amplificação foram visualizados sob luz ultravioleta e fotodocumentados para análise.

O polimorfismo cria um sítio de restrição para a enzima PstI no produto de PCR para o alelo CYP3A4*1B, apresentando um padrão de bandas como demonstrado no Quadro 2 (HASHIMOTO et al., 1993).
Sendo assim, após a padronização da PCR, no quesito DNA polimerase, foi realizada a PCR-RFLP das 60 amostras de DNA obtidas dos voluntários. A restrição enzimática foi realizada a $37^{\circ} \mathrm{C}$ por 1 hora, utilizando-se 8 $\mu \mathrm{L}$ de produto de PCR adicionados a $1 \mu \mathrm{L}$ da enzima de restrição PstI (Prodimol) e $1 \mu \mathrm{L}$ do seu tampão. Os produtos da digestão enzimática foram submetidos à eletroforese em gel de agarose $3 \%$, previamente corados com gel red (Uniscience) e visualizados em luz UV em 
Quadro 2 - Padrão de bandas do produto de PCR para o alelo CYP3A4*1B, pela digestão da enzima de restrição PstI.

\begin{tabular}{lcccc}
\hline Polimorfismo & Amplicom & Não portador & Portador heterozigoto & Portador homozigoto \\
\hline CYP3A4 & $334 \mathrm{pb}$ & $220,81,33 \mathrm{pb}$ & $220,199,81,33,21 \mathrm{pb}$ & $199,81,33,21 \mathrm{pb}$ \\
\hline
\end{tabular}

Fonte: Elaborado pelos autores

transluminador. Os resultados do polimorfismo foram analisados e reportados como porcentagem e frequência alélica dos mesmos.

\section{RESULTADOS}

O primeiro teste de DNA polimerase realizado foi com Platinum Taq DNA Polimerase (Invitrogen Life Technologies) está apresentado na Figura 1.

Figura 1 - Eletroforese em gel de agarose a $2 \%$ da PCR do polimorfismo CYP3A4*1B utilizando Platinum Taq DNA Polimerase (Invitrogen Life Technologies). MT: Ladder de 100 pb; 2, 3, 4, 5, 6, 7, 8, 9, e 10: amostras a serem testadas. Setas indicam o amplicon de $334 \mathrm{pb}$.

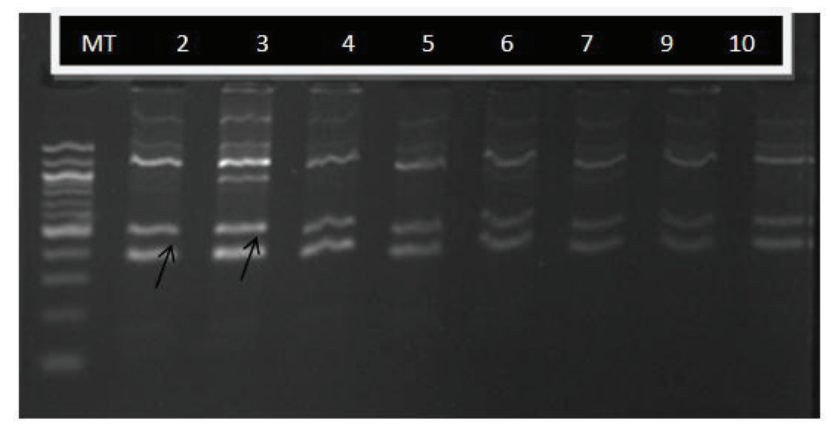

Fonte: Elaborado pelos autores

O resultado da corrida eletroforética das amostras amplificadas com a enzima Ampli Taq Gold (Invitrogen Life Technologies) encontra-se na Figura 2.

Figura 2 - Eletroforese em gel de agarose a $2 \%$ da PCR do polimorfismo CYP3A4*1B utilizando a Ampli Taq Gold (Invitrogen Life Technologies). MT: Ladder de 100 pb; 1, 2, 3, 4 e 5: amostras a serem testadas. Setas indicam o amplicon de $334 \mathrm{pb}$.

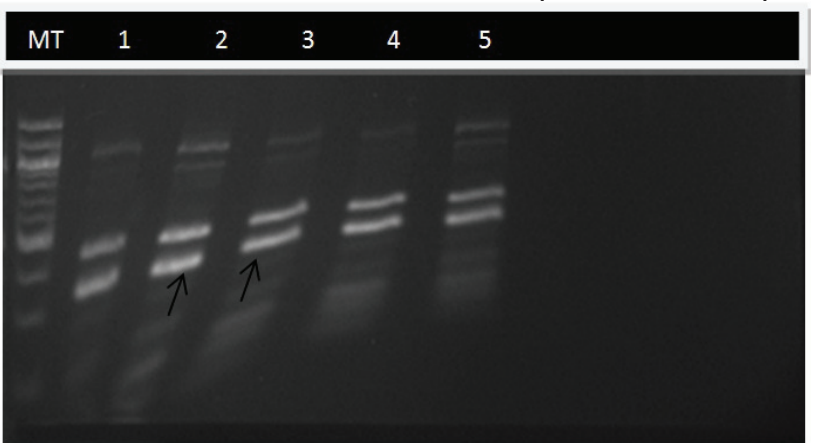

Fonte: Elaborado pelos autores

Na Figura 3 estão apresentadas os resultados da PCR com a enzima Hot Star Taq Poli- merase (Qiagen) e DNA Polimerase Master Mix Red (Amplicon - Neobio).

Figura 3 - Eletroforese em gel de agarose a 2\% da PCR do polimorfismo CYP3A4*1B utilizando a Hot Star Taq Polimerase (Qiagen) e DNA Polimerase Master Mix Red (Amplicon - Neobio). MT: Ladder de 100 pb; 1 e 2: Hot Star Taq Polimerase; 3: Controle Negativo; 4 e 5: DNA Polimerase Master Mix Red.

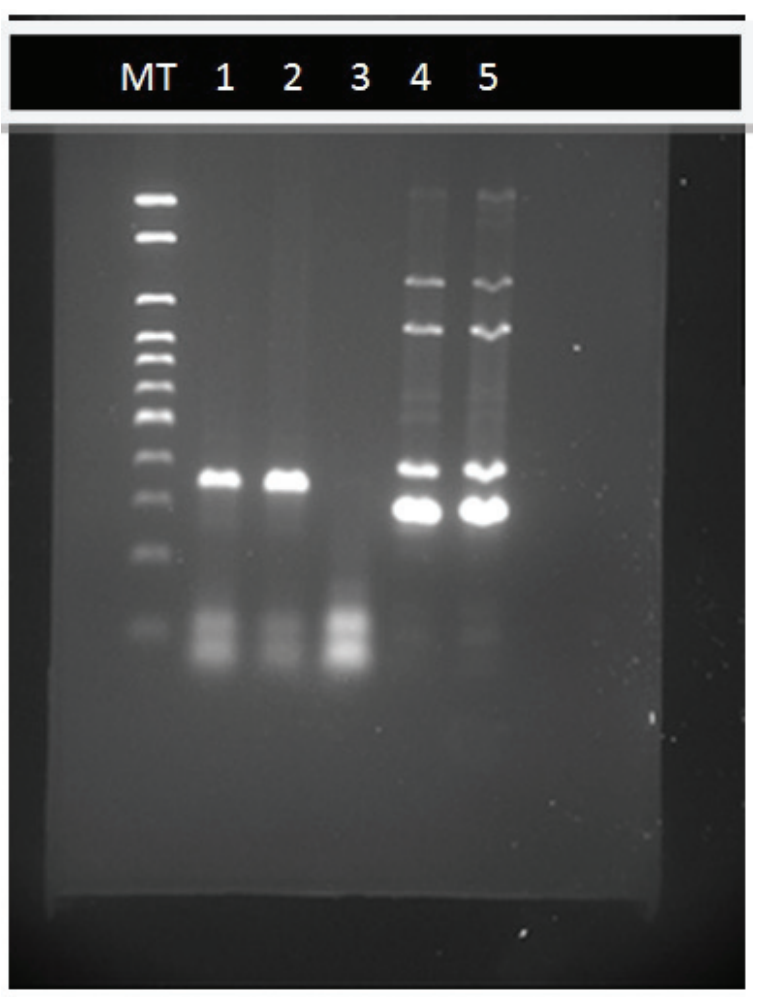

Fonte: Elaborado pelos autores

A Figura 4 (página 24) ilustra a eletroforese do corte enzimático com a distribuição das bandas do indivíduo considerado selvagem (220, 81 e 33 pb) e do portador heterozigoto (220, $199,81,33$ e 21 pb), de acordo com o padrão de badeamento demostrado no Quadro 2.

\section{DISCUSSÃO}

A reação em cadeia da polimerase é a técnica mais comumente utilizada para genotipagem e tem promovido diversos estudos sobre polimorfismos, associações de genótipos com risco de doença e seu prognóstico. Vários métodos de PCR estão disponíveis e cada um é adequado para a natureza de cada estudo, para a determinação do genótipo em questão. O tipo de polimorfismo, a precisão de genotipagem, o número de amostras, o equipamento disponível de PCR 
Figura 4 - Eletroforese em gel de agarose a 3\% da Restrição Enzimática com PstI para detecção do polimorfismo CYP3A4*1B. MT: Ladder de 100 pb; amostra 1 e 2: não portadores (ou alelo selvagem); amostra 3: portador heterozigoto; amostra 4 e 5: não portadores (ou alelo selvagem). Setas: tortuosa $220 \mathrm{pb}$; tracejada $199 \mathrm{pb}$; recortada 81 pb; inteira

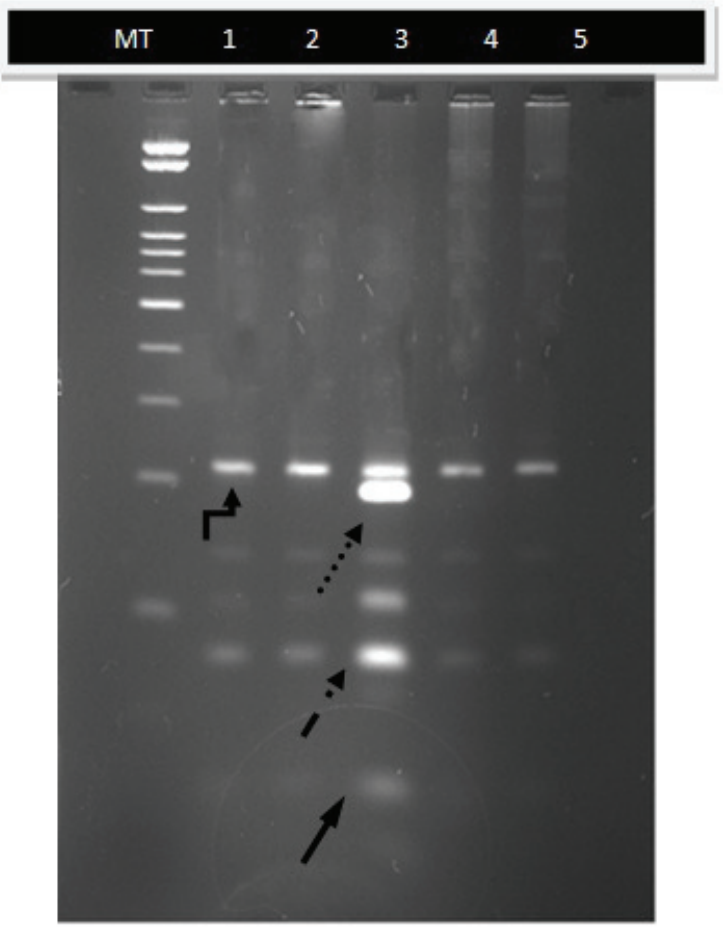

Fonte: Elaborado pelos autores

e as condições reacionais são fatores a serem levados em conta quando um método PCR é escolhido para um determinado tipo de estudo.

O polimorfismo CYP3A4*1B pode ser facilmente detectado com uma PCR seguida de restrição (digestão) enzimática, conhecida como PCR-RFLP. No intuito de reduzir as amplificações inespecíficas, observadas quando aplicada a PCR para o alelo CYP3A4*1B, procedeu-se a otimização da técnica, na qual foi analisado o efeito de diferentes DNA polimerases master mix no protocolo proposto por Ron e cols (2000), aumentando a especificidade do teste com a PCR do tipo Hot Star. Paralelamente, foi realizado um experimento para verificar o efeito inibidor do aumento da concentração de magnésio sobre os resultados da PCR (resultados não demonstrados).

Os resultados demonstraram que a PCR para o alelo CYP3A4*1B gera bandas inespecíficas (que pode ser pelo alto teor de C-G dos primers e pelo primer Fowerd possuir modificação de duas bases nitrogenadas na sua sequência) que podem ser amenizadas quando ajusta-se as condições reacionais para uma PCR do tipo Hot Star com DNA polimerases específicas para este tipo de técnica.

$\mathrm{Na}$ análise comparativa a Hot Star Taq (Qiagen) foi a DNA polimerase que apresentou menos bandas inespecíficas, sendo a mesma utilizada para as PCRs das amostras processadas. Embora ressalta-se que todas as DNA po- limerases utilizadas podem ser utilizadas para a realização da técnica, com maior atenção a Platinum Taq DNA Polimerase (Invitrogen Life Technologies), que apresentou o maior número de bandas inespecíficas. Deste modo, devido a dificuldade de diminuição por completo de bandas inespecíficas para algumas DNA polimerases sugere-se a aplicação de um testemunho não cortado (TNF) na corrida eletroforética do corte enzimático, para que a análise de bandas correspondentes aos alelos mutados e selvagens seja eficaz e sem enganos.

Em relação a quantidade de portadores homozigotos obteve-se uma porcentagem de $0,33 \%$, a porcentagem de heterozigotos foi de $21,67 \%$ e $75 \%$ dos indivíduos foram não portadores de polimorfismo em 60 pacientes estudados. A porcentagem de alelos de CYP3A*1B foi de $25 \%$. Dessa forma verifica-se que o polimorfismo CYP3A*1B é expressivo na população estudada, de apenas 60 pacientes. Em relação aos dados obtidos no cálculo de Hardy-Weinberg observa-se que a frequência genotípica esperada está bem próxima do equilíbrio.

Segundo Rebbeck et al. (1998) a variante, CYP3A4*1B, apresenta uma grande variação inter étnica na sua frequência, com 2,8-9,6\% em caucasianos, 48-67,2\% em afro-americanos, 69-81\% em africanos e estando ausente na população asiática. Na população portuguesa, a frequência descrita para a variante CYP3A4*1B é de 4-7 \% e o significado biológico do polimorfismo é controverso. Nos suecos, foram encontrados 3 alelos de CYP3A4*1B entre 39 indivíduos estudados, dando uma frequência alélica de 3,8\% Westlind et al. (1999) e Sata et al. (2000) relataram uma frequência alélica de 4,2\% em 59 indivíduos brancos analisados. Assim, observa-se que os dados obtidos no presente trabalho estão próximos da frequência alélica na população afrodescendente relatada nos estudos internacionais. Não foi possível uma consonância integral da frequência alélica obtida por outros pesquisadores, provavelmente pela característica peculiar de alta miscigenação populacional brasileira. Vale ressaltar ainda que, o Maranhão possui uma população extremamente heterogênea devido ao elevado tráfico de navios negreiros para a região (provenientes da África) e dos diferentes colonizadores (portugueses, holandeses e franceses).

Alguns estudos apontam que a presença da variante tenha como consequência uma diminuta expressão ou atividade da enzima (PHAROAH et al. 2002). Estes apontam ainda que a presença concomitante do polimorfismo CYP3A5 possa ser a ferramenta fundamental para a diminuição da expressão da enzima frente aos fármacos da classe das estatinas (SEMIZ et al,. 2001).

Esta técnica pode facilitar estudos sobre o efeito deste polimorfismo em processos endógenos, ambiental, susceptibilidade ao câncer e a capacidade individual para metabolizar 
drogas, sendo uma importante ferramenta na rotina terapêutica.

\section{CONSIDERAÇÕES FINAIS}

Em conclusão, este trabalho descreveu a optimização e validade da análise PCR-RFLP rápida e simples, para o alelo CYP3A4*1B. Além disso, observou-se uma frequência significativa de polimorfismo para o alelo CYP3A*1B na população estudada. Porém, mais estudos são necessários para demostrar se o polimorfismo de CYP3A4*1B leva a maior atividade enzimática CYP3A4 para diversas classes de fármacos, não só em sistemas de cultura de células, como na maioria dos estudos, mas também em indivíduos.

\section{REFERÊNCIAS}

BALL S.E. et al. Population distribution and effects on drug metabolism of a genetic variant in the 59 promoter region of CYP3A4. Clinical pharmacology \& therapeutics, n.66, p 288-94, 1999.

EISELT, R. et al. Identification and functional characterization of eight CYP3A4 protein variants. Pharmacogenetics, n.11,p.447-58,2001.

EVANS,W.E.; RELLING, M.V.

Pharmacogenomics: translating functional genomics into rational therapeutics. Science, n. 286, p. 487-91,1999.

GARCÍA-MARTÍN, E; MARTÍNEZ, C; PIZARRO, $M$. CYP3A4 variant alleles in white individuals with low CYP3A4 enzyme activity. Clinical pharmacology \& therapeutics, v. 71, n 3, 2002.

HARDRYS, H.; BALICK, M; SCHIERWATER, B. Applications of random amplified polymorphic DNA (RAPD) in molecular ecology. Molecular Ecology, n. 1, p. 55-66. 1992.

HASHIMOTO, $\mathrm{H}$ et al. Gene structure of CYP3A4, an adult-specific form of cytochrome P450 in human livers, and its transcriptional control. European Jornal of Biochemistry n.218,p.585- 95, 1993.

INGELMAN-SUNDBERG, M; OSCARSON, M; MCLELLAN, R.A. Polymorphic human cytochrome P450 enzymes: an opportunity for individualized drug treatment. Trends in pharmacological Science, n.20,p.342-349, 1999.

KITADA, M. et al. Significance of cytochrome P-450 ( $P$-450 HFLa) of human fetal livers in the steroid and drug oxidations. Biochemical Pharmacology, n.36,p.453-456, 1987.

MEUNIER, J.R.; GRIMONT, P.A.D. . Factors affecting reproducibility of random amplified polymorphic DNA fingerprinting. Resarch in Microbiology, n.144, p. 373-379,1993.

OZDEMIR, V. et al. Evaluation of the genetic component of variability in CYP3A4 activity: a repeated drug administration method. Pharmacogenetics, n.10, p.373-88, 2000.

PHAROAH, P.D. et al. Polygenic susceptibility to breast cancer and implications for prevention. Nature Genetics, n. 31,p.3336,2002

REBBECK, T.R. et al. Modification of clinical presentation of prostate tumors by a novel genetic variant in CYP3A4. Jornaul of National Cancer Insitute, n. 90, p.1225-9, 1998.

RODRIGUEZ-ANTONA, C. et al. Phenotypegenotype variability in the human CYP3A locus as assessed by the probe drug quinine and analyses of variant CYP3A4 alleles. Biochemical and Biophysical Research Communication, n.338, p.299-305. 2005.

RODRIGUEZ-ANTONA, C.; INGELMANSUNDBERG, M. Cytochrome P450 pharmacogenetics and câncer. Oncogene, n.25, p.1679-1691, 2006.

RON, H.N. et al. CYP3A4-V Polymorphism detection by PCR-restriction fragment length polymorphism analysis and its allelic frequency among 199 dutch Caucasians. Clinical Chemistry, n. 11,p.46, 2000.

SAMBROOK, J.; RUSSEL, D. W. The condensed protocols from molecular cloning: a laboratory manual. New York: Cold Spring Harbor Laboratory Press, 2006.

SATA, F. et al. CYP3A4 allelic variants with amino acid substitutions in exons 7 and 12: evidence for an allelic variant with altered catalytic activityCYP3A4 allelic variants with amino acid substitutions in exons 7 and 12: evidence for an allelic variant with altered catalytic activity. Clin. Pharmacol Ther. v. 67, n. 1, p. 48-56, 2000.

SEMIZ, S. et al. Analisis of CYP3A4*1B and CYP3A5*3 polimorphisms in population of Bosnia and Herzegivinia. Med Glas Ljek Komore Zenicko-doboj Kantona, n. 8, v. 1, p. 84-89, 2001.

WAXMAN, D.J. et al. Human liver microsomal steroid metabolism: identificationof the major microsomal steroid hormone 6 betahydroxylasecytochrome P-450 enzyme. Archives of Biochemistry and Biophysic, n. 263,p.424-436, 1988.

WESTLIND, $A$. et al. Interindividual differences in hepatic expression of CYP3A4: relationship to genetic polymorphism in the 59-upstream regulatory region. Biochemical and Biophysical Research Communication, $\mathrm{n}$. 259,p.201-5, 1999.

WOLFF, K.; SCHOEN, E.D.J. PETERSVAN RIJN. Optimizing the generation of random amplified polymorphic DNAs in chrysanthemum. Theoretical and Applied Genetic, n. 86,p. 1033-1037, 1993. 